\title{
PEMBELAJARAN BERBASIS NILAI PADA MATAPELAJARAN SEJARAH MELALUI MODEL VCT (VALUE CLARIFICATION TECHNIQUE)
}

\author{
Putri Nur Ekasari \\ Pendidikan Sejarah Pascasarjana, Universitas Negeri Malang
}

\begin{abstract}
Abstrak: Hasil belajar sejarah tidak hanya berkaitan dengan aspek pengetahuan saja. Peserta didik sudah selaknya merasakan kebermaknaan sejarah bagi diri mereka. Disamping mengenai fakta-fakta sejarah yang disajikan dalam bentuk permasalahan yang problematis, pembelajaran sejarah juga perlu dikemas dengan memperhatikan nilai-nilai. Peserta didik diharapkan mampu mengambil nilai dari sebuah peristiwa sejarah kemudian mereka dapat mempertimbangkan nilai tersebut apakah cocok bagi diri mereka. Pembelajaran sejarah yang demikian itu nantinya akan berguna bagi peserta didik sebagai bahan pertimbangan untuk bertindak. Tulisan ini akan menggambarkan pembelajaran sejarah yang melibatkan aspek nilai yaitu dengan pembelajaran sejarah berbasis nilai melalui model pembelajaran VCT (Valaue clarification Technique). Model pembelajaran ini memberikan kesempatan bagi peserta didik untuk menemukan, dan menganalisis nilai pada setiap peristiwa sejarah. Peserta didik tidak hanya sekedar dihadapkan pada fakta sejarah melainkan juga dituntut untuk menemukan nilai. Terlebih dapat menentukan apakah nilai tersebut masih relevan bagi dirinya.
\end{abstract}

Kata-Kata Kunci: pembelajaran berbasis nilai, VCT, fakta sejarah, belajar bermakna

\begin{abstract}
The result of history learning is not only related to the knowledge aspect. Learners have selaknya sense of historical significance for themselves. Besides the historical facts presented in the form of problematic problems, historical learning also needs to be packed with attention to the value-nili. Learners are expected to take the value of a historical event then they can consider the value of whether it suits them. Such historical learning will be useful for learners as a consideration for action. This paper will describe a history learning that involves the value aspect of learning based on value-based learning through the VCT (Valaue clarification Technique) learning model. This learning model provides an opportunity for learners to discover, and analyze the value of each historical event. Learners are not only faced with historical facts but also are required to find value. Moreover can determine whether the value is still relevant for him.
\end{abstract}

Keywords: value-based learning, VCT, historical fac, meaningful learning

Dewasa ini penyelenggaran pembelajaran sejarah di sekolah masih terus mengalami inovasi. Berbagai macam penelitian berkaitan dengan pembelajaran sejarah 
masih terus dilakukan demi tercapainya tujuan pembelajaran sejarah. Tujuan pembelajaran sejarah di sekolah tidak hanya berkaitan dengan kemampuan siswa untuk menguasai materi sejarah. Masih ada aspek afektif dan psikomotorik yang juga harus diperhatikan oleh guru sejarah. Namun hal ini yang justru sering kali dilupakan. Selama ini praktek pembelajaran sejarah di sekolah masih cenderung pada proses transfer informasi. Meskipun suasana pembelajaran yang dirancang oleh guru mengharuskan peran aktif dari peserta didik, tetap saja semua itu hanya berkaitan dengan ketercapaian kemampuan dalam ranah pengetahuan saja. Pembelajaran sejarah yang dirancang belum sampai pada kebermaknaan dan kebermanfaatan pada diri peserta didik.

Hariyono (2006: 80) menyatakan bahwa perlu pendidikan sejarah di level pendidikan dasar dan menengah bukan untuk menciptakan ahli sejarah, melainkan lebih diutamakan untuk membekali peserta didik dalam mengantisipasi permasalahan kehidupan sehingga memiliki otonomi diri. Hal tersebut sudah selakyanya disadari oleh guru sejarah. Pengetahuan kesejarahan memang menjadi keharusan, namun kebermaknaan sejarah untuk diri peserta didik juga harus tetap diperhatikan. Pembelajaran sejarah yang dirancang bukan lagi sekedar guru menyampaiakan informasi mengnai faktafakta sejarah, kemudian siswa dihadapkan pada permasalahan problematis dan diminta untuk memecahkannya.

Lebih dari itu guru hendaknya juga harus memikirnkan manfaat bagi diri peserta didik dalam menghadapi permasalahan di kehidupan sehari-hari. Untuk itulah diperlukan model pembelajaran sejarah yang dapat mewujudkan tujuan tersebut. Melalui tulisan ini akan diketahui gambaran pelaksaan pembelajaran sejarah yang memungkin terjadinya kebermaknaan bagi diri peserta didik dan yang terpenting tidak hanya untuk mencapai kemampuan kognitif saja. Model pembelajaran yang akan ditawarkan pada tulisan ini yaitu dengan menggunakan pembelajaran berbasis nilai melalui model VCT (Valaue clarification Technique).

\section{PEMBELAJARAN BERBASIS NILAI PADA MATAPELAJARAN SEJARAH}

Menurut Hill (1956:147) guru sejarah hendaknya tidak hanya sekedar mengajarkan kebijaksanaan bagi siswanya melainkan juga bagaimana mengambil hikmah dari sebuah peristiwa. Berdasarkan pendapat tersebut dapat dipahami bahwa selain kebijaksaan pembelajaran sejarah harus mampu mengantarkan peserta didik pada tahap mengambil hikmah dari sebuah peristiwa sejarah. Mengambil hikmah dapat dilakukan dengan cara menemukan nilainilai yang ada pada setiap peristiwa sejarah. Setiap peristiwa sejarah pasti memiliki nilai, karena pada dasarnya nilai tersebut selalu menyertai disetiap kehidupan di masa lalu.

Guru sejarah tidak cukup hanya memberikan gambaran mengenai kehidupan masa lamapau dengan menyajikan fakta-fakta sejarah. Peserta didik juga tidak cukup hanya dihadapakan pada permasalahanyang mengharuskan mereka untuk menyelasaikannya. Terlebih masalah tersebut berkaitan dengan masa lampau yang jauh dari diri peserta didik. Amin (2011: 107) juga menyatakan bahwa ada jarak yang relatif jauh antara materi pelajaran yang diajarkan di sekolah dengan realitas yang dihadapi siswa di masyarakat. Teori-teori yang diajarkan oleh guru pelajaran sejarah kadang tidak 
tepat atau malah berbeda dengan yang dihadapi siswa dalam realitas masyarakat. Hal ini yang kadang membuat siswa tidak suka dengan pelajaran sejarah karena cenderung hanya hafalan dan tidak aplikatif.

Oleh karena itu, guru sejarah perlu menciptakan pembelajaran sejarah yang dekat dengan diri siswa salah satu caranya adalah dengan memunculkan keterkaitan antara sejarah dengan diri peserta didik. Salah satu cara yang dapat digunakan guru adalah mengahdirkan masalah nilai-nilai. Melalui nilai-nilai itu peserta didik dapat belajar lebih bijaksana dan mampu mengambil hikmah sehingga mereka akan lebih merasakan bahwa sejarah itu ternyata juga bermanfaat bagi diri mereka.

Jika merujuk pada kurikulum 2013 salah satu karakteristik matapelajaran sejarah adalah suatu proses internalisasi nilai-nilai, pengetahuan dan keterampilan kesejarahan dari serangkaian peristiwa yang dirancang dan disusun sedemikian rupa untuk mempengaruhi dan mendukung terjadinya proses belajar peserta didik. Berdasarkan pernyataan tersbut sangat jelas bahwa pembelajaran sejarah dilaksanakan tidak cukup hanya menyajikan fakta-fakta sejarah, lebih dari itu pembelajaran sejarah harus mampu sampai pada tahap internalisasi. Internalisasi yang dimaksud adalah pengetahuan yang didapatkan peserta didik dapat digunakan sebagai bahan pertimbangan menyikapi suatu permasalahan kemudian secara tidak langsung diikuti dengan tindakan.

Sesuai dengan tuntutan kurikulum 2013 maka tahap internalisasi yang dimaksud mencakup nilai-nilai, pegetahuan dan keterampilan. Nilai-nilai inilah yang akan dikaji lebih dalam pada tulisan ini. Hal ini juga berangkat dari permasalahan dalam pembelajaran sejarah yang belum mengintegrasikan masalah nilai dalam pembelajaran sejarah. Guru masih terlalu berfokus pada aspek pengetahuan peserta didik. Untuk itulah diperlukan alternatif solusi berupa pembelajaran berbasis nilai pada pembelajaran sejarah agar memudahkan proses internalisasi tersebut.

Frankel (1977:6) mengemukakan bahwa nilai adalah idea atau konsep yang bersifat abstrak tentang apa yang dipikirkan seseorang atau dianggap penting oleh sesorang, biasanya mengacu kepada estetika (keindahan), etika pola prilaku dan logika benar salah atau keadilan justice. Sejalan dengan hal tersebut, Kuntjaraningrat (1992:26) menyebutkan sistem nilai budaya terdiri dari konsepi-konsepi yang hidup dalam alam pikiran sebagian besar keluarga masyarakat, mengenai hal-hal yang harus mereka anggap bernilai dalam hidup. Sedangkan menurut penulis, nilai dalam peristiwa sejarah merupakan tentang sesuatu yang dianggap baik dan benar sesuai dengan norma dan aturan yang berlaku pada masyarakat dan terkandung dalam setiap peristiwa masa lampau.

Pembelajaran berbasis nilai-nilai adalah pembelajaran yang digunakan guru untuk memfasilitasi peserta didik dalam menguasai seperangkat rumusan kompetensi, dengan mengedepankan dan mengacu pada nilai-nilai (Gufron dkk, 2017:310). Pembelajaran berbasis nilai dapat disajikan melalui analisis nilai-nilai. Peserta didik dapat menemukan nilai dibalik peristiwa sejarah terntu kemudian menganalisis nilai-nilai tersebut. Pembelajaran berbasis nilai lebih mengedepankan masalah nilai yang dapat digunakan sebagai bahan pertimbangan peserta didik dalam bertindak. Diharapkan pembelajaran berbasis nilia dapat memperkuat karakter peserta didik sesuai dengan harapan kurikulum 2013. 
Meskipun berkaitan dengan analisis nilai, tidak akan menghilangkan kedudukan sejarah sebagai ilmu. Guru sejarah juga tetap harus menampilkan fakta-fakta, dan nilai yang coba dianalisis peserta didik juga berdasarkan fakta tersebut. Pembelajaran berbasis nilai membutuhkan keterpaduan antara aspek kognitif, afektif dan psikomotik. Pada taraf kognitif peserta didik dihadapkan pada fakta sejarah. Pengetahuan kesejarahan ditonjolkan pada tahap ini. Ketika peserta didik memiliki pengetahuan kesejarah yang luas selanjutnya mereka dihadapkan pada permasalahan mengenai nilai-nilai. Nilai yang ditemukan dan selanjutnya dianalisis dapat digunakan sebagai bahan pertimbangan untuk menyikapi permasalahan. Pada tahap keterampilan diharapkan peserta didik benar-benar menggunakan nilai yang pernah mereka pelajari melalui peristiwa sejarah tertentu kemudian mereka berhasil menganalisisnya dan digunakan untuk menyikapi permasalahan, tahap terkahir adalah tindakan. Tindakan yang diharapkan adalah ketika peserta didik mampu menyikapi suatu permasalahan selanjutnya mereka diharapkan dapat bertindak sesuai dengan sikap yang telah mereka pertimbangkan.

Jika pembelajaran berbasis nilai dapat diterapkan maka fungsi utama dari pembelajaran sejarah akan tercapai. Widja (1989:57) menyatakan bahwa salah satu fungsi utama sejarah adalah mengabadikan pengalaman masyarakat di masa lampau, yang sewaktu-waktu dapat digunakan sebagai bahan pertimbangan bagi masyarakat itu dalam memecahkan masalah yang dihadapinya. Melalui sejarahlah nilai-nilai masa lampau dapat dipetik dan digunakan untuk mengahdapi masa kini.

\section{MODEL PEMBELAJARAN VCT (VALUE CLARIFICATION TECHNIQUE)}

Adisusilo (2012:41) menyatakan bahwa penekanan VCT adalah pada pemilihan dan penentuan nilai secara bebas serta sikap terhadapnya. Hal yang sangat penting dalam model pembelajaran ini adalah mengembangkan ketrampilan peserta didik dalam proses menilai dan mengambil keputusan. Nilai bersifat subjektif, dipilih oleh seseorang berdasarkan pada berbagai pertimbangan nalarnya sendiri, tidak ditentukan secara sepihak oleh agama, maupun masyarakat. Berrdasarkan pendpaat tersebut dapat diketahui bahwa model pembelajaran VCT akan memberikan banyak kesempatan bagi pserta didik untuk belajar mengenai nilai. Peserta didik tidak hanya dihadapkan pada fakta sejarah melainkan juga mengenai nilai-nilainya. Terlebih nilai tersebut digali sendiri oleh peserta didik. Proses inti tentunya akan menjadikan pembelajaran lebih bermakna bagi peserta didik.

Salah satu karakteristik VCT adalah proses penanaman nilai dilakukan melalui proses analisis nilai yang sudah ada dalam diri siswa kemudian menyelaraskannya dengan nilai-nilai baru yang akan ditanamkan. Pembelajaran VCT dapat dilaksanakan dengan menggunakan berbagai metode seperti Value problem solving, diskusi, dialog, dan presentasi (Sadono \& Masruri, 2014:74). Model pembelajaran VCT dapat dikatakan menjadikan lebih bermakna dan peserta didik dapat merasakan manfaatnya ketika nilai yang telah ditemukan dianalisis peserta didik harus diselaraskan dengan nilai yang telah melekat pada diri peserta didik. Melalui model ini peserta didik membutuhkan kemampuan berpikir analis 
dan menyelaraskan dengan apa yang sudah mereka miliki. Sehubungan dengan hal itu, maka kemampuan berpikir tingkat tinggi juga sangat dibutuhkan pada model pembelajaran ini.

Pada penelitian ini VCT dapat dikatakan sebagai model pembelajaran mengacu pada pendapat Joyce \& Weil (2009: 31) yang menyatakan bahwa ciri model pembelajaran adalah sebagai berikut.

1. berdasarkan teori pendidikan dan teori belajar dari para ahli tertentu.

2. mempunyai misi atau tujuan pendidikan tertentu.

3. dapat dijadikan pedoman untuk perbaikan kegiatan belajar mengajar di kelas.

4. memiliki bagian-bagian model dalam pelaksanaan, yaitu: urutan langkah-langkah pembelajaran.

5. memiliki dampak sebagai akibat terapan model pembelajaran.

Sebagai model pembelajaran VCT dirancang berdasarkan teori belajar kognitif karena pada tiap langkahnya diperlukan kemampuan berpikir yang sistematis. Visi dari model pembelajaran VCT adalah berkaitan dengan pembelajaran berbasis nilai agar peserta didik dapat menemukan dan menganalisis nilai untuk kemudian disesuaikan dengan nilai yang sudah ada pada diri mereka. Nilai yang telah diputuskan untuk dijadikan milik dirinya akan berguna untuk menyelsaiakn permasalahan yang muncul dalam kehidupan sehari-hari, sehingga proses belajar yang mereka lalui akan dirasakan manfaatnya secara langsung. Model pembelajaran VCT juga dapat digunakan untuk memperbaiki praktek pembelajaran sejarah agar lebih baik terlebih jika menginginkan pembelajaran sejarah yang dirasakan memberikan manfaat bagi peserta didik untuk menghadapi permasalahan kehidupan. Model pembelajaran VCT memiliki langkah-langkah yang jelas sehingga dapat disebut sebagai model pembelajaran. Langkah-langkah VCT adalah (1) kegiatan pendahuluan, terdiri dari: (a) mempersiapkan kondisi pembelajaran, (b) mendiskusikan tujuan pembelajaran, (c) melakukan apersepsi; (2) Kegiatan inti, terdiri dari: (a) menyajikan dilema, (b) peserta didik tugas mandiri (c) membentuk diskusi kelompok kecil, (d) diskusi pleno kelas, (e) penutup diskusi kelas (3) Kegiatan penutup, terdiri dari: (a) membuat kesimpulan, (b) memberikan melakukan penilaian.

Menurut Kirschenbaum (2000: 5) model pembelajaran VCT memiliki empat bahan pokok. Pertama, topik yang dipilih sarat dengan nilai atau isu moral. Kedua, guru atau ketua kelompok (jika menggunakan metode diskusi) mengajukan pertanyaan atau aktivitas yang berkaitan dengan klarifikasi nilai untuk membantu peserta berpikir, membaca, menulis, dan berbicara tentang topik. Ketiga, selama proses pembelajaran berlangsung harus menumbuhkan rasa saling menghormati pendapat orang lain. Keempat saling menghargai dan bersikap bijaksan terhadap nilai yang telah dipilih. Peserta didik harus memahami segala konsekuensi dari nilai yang telah mereka pilih jika diterapkan dalam berperilaku.

Jika diterapkan dalam pembelajaran khususnya sejarah tentunya akan memberikan dampak bagi proses pembelajaran itu tersendiri khususnya bagi peserta didik. Seperti contohnya dampak yang ditimbulkan setelah menggunakan model pembelajaran VCT dilihat dari hasil belajar sejarahnya. Beberapa penelitian telah melaporkan bahwa model VCT ini memberikan dampak bagi hasil belajar. Hasil penelitian Wibowo (2015:79) membuktikan bahwa VCT merupakan 
dapat mengimplikasikan perubahanperubahan dalam kognisi melalui pengetahuan dan informasi, dan ketampilan baru, serta perubahan dalam segi afektif yang berhubungan dengan perasaan, sikap, dan emosi. Melalui VCT membantu peserta didik untuk berubah, sehingga mereka bertindak dengan cara yang lebih dapat diterima, baik secara personal maupun sosial.

\section{PENUTUP}

Model pembelajaran berbasis nilai melalui VCT dalam pembelajaran sejarah dapat menambah alternatif pilihan bagi guru sejarah demi mencapai tujuan pembelajaran sejarah yang seutuhnya. Selain itu ditengah berbagi macam masalah dalam pembelajaran sejarah khususnya berkaitan dengan kurangnya rasa kebermanfaatan sejarah bagi diri peserta didik, nampaknya model pembelajaran ini sangat cocok digunakan untuk mengatasi masalah tersebut. Selain itu langkah-langkah yang ditawarkan oleh model pembelajaran ini mampu mengantarkan peserta didik pada hasil belajar sejarah yang lebih seimbang. Keseimbangan yang dimaksud adalah keterpaduan antara aspek kognitif, afektif dan psikomotorik. Namun, hal ini masih perlu dilakukan pengkuran lebih lanjut melalui penelitian eskperimen.

\section{DAFTAR RUJUKAN}

Adisusilo, S. 2012. Pembelajaran Nilai Karakter: Konstruktivisme dan VCT Sebagai Inovasi Pendekatan Pembelajaran
Afektif. Jakarta: Raja Grafindo.

Amin, S. 2011. "Pewarisan Sejarah Nilai Lokal Melalui Pembelajaran Sejarah Pada Jalur Formal dan Informal Pada Siswa di SMA Kudus Kulon”. Jurnal Paramita, 21(1). Universitas Negeri Semarang.

Joyce, B., dkk. 2009. Models of Teaching. Terj Achmad Fawaid dan Ateilla Mirza. Englewood Cliffs. New Jersey: Prentice Hall, Inc.

Hill, C.P. 1956. Saran-Saran Tentang Mengajarkan Sejarah. Jakarta: Perpustakaan Perguruan Kementrian.

Fraenkel, J.R. 1977. How to Teach About Values: An Analytic Approach. New Jersey: Prentice Hall, Inc.

Ghufron, A dkk. 2017. "Pengembangan Pembelajaran Berbasis NilaiNilai Budaya Yogyakarta Di Sekolah Dasar". Jurnal Cakrawala Pendidikan. 36(2). 318-309. Yogyakarta: Universitas Negeri Yogyakarta.

Kirschenbaum, H. 2000. From Values Clarification to Character Education: A Personal Journey. Journal of Humanistic Counseling, Education And Development. 39. (Online) http://onlinelibrary.wiley.co $\mathrm{m} / \mathrm{doi} / 10.1002 / \mathrm{j} .2164-$ 490X.2000.tb00088.x/full.

Koentjaraningrat. 1992. Beberapa Pokok Antropologi Sosial. Jakarta: Dian Rakyat.

Sadono, M. Y. \& Masruri, Muhsinatun Siasah. 2014. Keefektifan 
VCT Dalam Pembelajaran Sejarah Untuk

Meningkatkan Nilai

Nasionalisme, Demokrasi, Dan Multikultural. Jurnal Harmoni Sosial. 1 (1). Yogyakarta: Universitas Negeri Yogyakarta.

Wibowo, A. 2015. Keefektifan Metode Klarifikasi Nilai Dalam Meningkatkan Karakter Siswa Pada Mata Pelajaran PKN. Jurnal JIPSINDO. 1 (2). 66-82. Dari https://journal.uny.ac.id/inde x.php/jipsindo/article/downl oad/4525/3897.

Widja,I.G. $1989 . \quad$ Dasar-Dasar Pengembangan Strategi Serta Metode Pengajaran Sejarah. Jakarta: DEPDIKBUDRISTEK. 